\title{
The affordances and limitations of collaborative research in the TESOL classroom
}

\author{
Yvette Slaughter and Julie Choi \\ The University of Melbourne
}

David Nunan

The University of Hong Kong

\section{Hayley Black, Rebecca Grimaud and Hân Trinh}

Carringbush Adult Education

\begin{abstract}
The diversity of learning needs within the TESOL field creates inherent tensions between the need for targeted professional learning for TESOL teachers, the more generalist nature of tertiary TESOL courses, and the varied research interests of teacher educators. This article describes a collaborative research project between university-based teacher educators and TESOL teachers working in an adult education centre. With a range of aims amongst the research participants, this article reports on the 'fluid' and 'messy' process of collaborative research (Burns $\mathcal{E}^{\circ}$ Edwards, 2014, p. 67) as we investigate the use of identity texts (Cummins $\mathcal{E}$ Early, 2011) as a mediating tool for professional learning. In acknowledging the practice of teaching as highly situated, the data presented focuses on the individual experience of each teacher, voiced through an action research frame, before we discuss the achievements and challenges which emerged through this collaborative research process. In the findings, we argue for the importance of championing the case for the messy processes of collaborative research within the broader research academy.
\end{abstract}

Key words: Collaborative research, professional learning, teacher educators, adult education, identity texts

\section{Introduction}

This article examines the tensions which arise at the theory practice nexus within practice-oriented research in the TESOL 
field. In particular, it interrogates the competing aims, intentions and necessary compromises between research partners, and the ongoing imperative to understand and actualise research frameworks which support reciprocal and symbiotic relationships between Second Language Acquisition (SLA) research and pedagogy in practice. The extent to which SLA research has been able to directly impact on teaching pedagogy has been an issue of contention for many decades (e.g., Ellis, 1997; Nassaji, 2012; Smith, 2017; Spada, 2013). In making this point, we are not drawing attention to the continuing endeavour to articulate a clear theory of second language acquisition (VanPatten \& Williams, 2015) nor of second language teaching (Spada, 2013). Rather, we seek to highlight the challenge in the 'messy' and 'fluid' nature of collaborative research (Burns \& Edwards, 2014, p. 67) which seeks to support differentiated interests within the constraints of context and the divergent needs of academic and practitioner researchers.

The frame through which this article is written is a research project driven by an academic interest in recent theoretical changes in SLA, namely translanguaging theory and the use of identity texts in SLA classrooms. The potential of any pedagogical intervention is of course dependent on a wide range of influences, including each teacher as an individual, their lived experiences, as well as their professional journeys (e.g., Ellis, 2016; Slaughter \& Cross, 2020). The purpose of the research project, therefore, was not to look for commonalities, but for situated interpretation and implementation of the same pedagogical tool across classroom settings. As Shulman (2007, p. 560) argues, 'to take seriously the world of practice and the intelligence that guides it is to recognize the stunning range of practices that characterizes the work of educators'. To this end, from within the broader research project, this article focuses in on the individual experiences of three classroom teachers, and their relationship with the broader aims of the collaborative partners.

In bringing these threads together, in this article, we describe a project, funded by VicTESOL, a professional teacher association for teachers of English language learners, involving a collaboration between university-based teacher educators and TESOL teachers of adult learners. The project took place at an intensive language centre for adult migrants and refugees in Melbourne, Australia. The aim of the broader project was to collaboratively explore and document effective teaching practices 
when working with adult learners with low levels of language and literacy in their first language, as well as in English. Identity texts were used as a reflection tool as part of an iterative cycle of practice and reflection, in which teachers were able to identify areas of teaching to focus on and improve.

We begin by discussing the inherent tensions between professional learning and research needs of both teacher educators and teachers, and the challenge in investigating theoretical developments in practice, before moving onto the research frame and context. The data presented focuses on the individual experience of each teacher, voiced through an action research frame, before we discuss the achievements and challenges which emerged through this collaborative research process, and the importance of championing the case for the messy processes of collaborative research within the broader research academy.

\section{Navigating the theory-practice nexus}

The diversity of learning needs within the TESOL field creates inherent tensions between the need for ongoing professional development for TESOL teachers, the more generalist nature of tertiary TESOL courses, for both pre- and in-service teachers, and the varied research interests of teacher educators. These complexities can contribute to endemic tensions between university-based academics and practicing teachers given the sometimes competing professional practice and research agendas. Teacher educators, for example, must balance their work as teacher educators as well as their work as academic researchers. As teacher educators, reflection on their own experiences of working with pre-service and in-service teachers, including what informs their approach to teacher training, is imperative (MacPhail et al., 2018). In addition to researching and understanding their own practices, there is a fundamental need for teacher educators to understand the evolution of language teacher learning, that is, the relationship between what students learn in formal teacher education, and through practical work experience, and then how they interpret and enact language teaching in their physical classrooms (Freeman \& Richards, 2002).

Observing and understanding teachers in practice is therefore a critical part of the teaching and research cycle for teacher educators but with the opportunity to be engaged with student teacher placements in schools quickly disappearing from teacher training programs, teacher educators can feel 'somewhat 
removed from the reality of teaching' (MacPhail et al., 2019, p. 855). To access classrooms as research sites, teacher educators often spend a substantial amount of time applying for grants and generating research funding, which, if successful, would allow them to interrogate their research agendas. In addition, in working in an increasingly competitive research environment, academics are expected to produce research, often driven by metrics-based publication expectations, which further theoretical as well as pedagogical knowledge (Moosa, 2018), although, this does not necessarily link directly with the varied needs of teachers in classrooms.

For TESOL teachers, tensions can exist between the broader pedagogical knowledge gained through tertiary studies and the specific pedagogical knowledge required once their working context is established or changes (e.g., DeCapua, Marhsall, \& Fryland, 2018; Grierson, 2010). It is also important to be mindful that education contexts, the applicability of pedagogical practices, and what is feasible within any context are highly situated, and closely linked to the socio-political environment, relationships with funding and employment authorities, and prevailing educational frameworks (Cross, 2010; Johnson, 2009; Scanlon Institute, 2019). Barnard and Burns (2012, p. 3) argue that there can often be a disconnect between what teachers believe and what they are able to put into practice due to the situated nature of teaching, as the affordances and constraints of teaching are influenced by a range of "physical, temporal, cognitive, social and cultural factors'. These conditions can also disrupt the transmission process from professional learning into classroom practice.

Research projects that involve academics (as teacher educators and as researchers) and practising teachers can therefore be somewhat fraught, caught between the tensions of how to facilitate research-focused as well as professional learning relationships with sometimes competing agendas. This can include research agendas that a) seek to address the need for teacher educators to sustain proximity of knowledge to teaching practices, b) allow continuation of professionally relevant research trajectories, and c) allow practicing teachers to access professional learning as well as supporting reflective investigation of their own practices, informed by the requirements of their teaching contexts.

One of the biggest challenges, therefore, is in designing research projects beyond the extremes of teacher as passive participant or teacher as sole participant in research (Burns, 
2019), while also attending to the complexity of teachers' and teacher educators/researchers' agendas. For this research project, the underlying aims for the different participants were as follows:

a) As teacher educators, we sought to develop our understanding of the challenges teachers face in investigating their own practice and to facilitate the professional learning of the teachers, as well as to further our understanding of how teachers unpack, interpret and apply new theoretical understandings and pedagogical approaches within a particular teaching context.

b) For Hayley, a teacher, as well as an alumni student who had taken classes with both Julie and Yvette, the focus was on taking theoretical concepts learnt in classes and understanding their affordances and limitations in practice.

c) For Rebecca and Han, participation of the project was initiated by fellow teacher Hayley and driven by an interest in participating in research as a form of professional learning, as well as exploring the potential of new approaches in an adult teaching context.

\section{The research context: Professional learning in the adult education space}

The research focus for this project was the use of innovative pedagogical tools when working with adult learners of English with low levels of literacy in their first language. The reasons for migrant English language learners lacking print literacy are varied and complex and teachers of adult learners are faced with the challenge of teaching English language and literacy to learners who have low literacy in a first language, who may have had little exposure to (written) literary traditions and practices, and some learners who have limited experience of schooling itself (e.g., Abur \& Spaaij, 2016; Bigelow \& Lovrien Schwarz, 2010). An addition, in comparison to other fields within TESOL education, a smaller, albeit growing, range of research has focused on teacher practice and pedagogy when working with low-literacy adult learners of English (e.g., Blackmer \& Hayes-Harb, 2016; Burt, Peyton, \& Adams, 2003; DeCapua \& Marshall, 2011).

Little research to date, however, has focused on the complex relationship between developing literacy skills in adult English language learners, while creating space for expression of self, that is, the relationship between language and identity. Cummins' 
(e.g., 2007, 2009) notion of identity texts is playing a critical role in the area of language and identity, moving the conceptualisation of literacy beyond traditional definitions of 'linear print-based reading and writing skills' to one which incorporates multilingual literacies and new literacies (Cummins, Hu, Markus \& Montero, 2015 , p. 557). Work with identity texts endeavours to document and reflect learners' identities in positive transformative ways and can include a range of multimodal forms, such as 'written, spoken, signed, visual, musical [and] dramatic' texts, among others (Cummins \& Early, 2011, p., 3).

Although the project involved the integration of identity texts into a ten-week term (see Research method section), teacher agency was of central importance and teachers were able to take their investigations in the direction that related most to their own professional learning needs. This article therefore focuses on the fluidity of collaborative research, and seeks to answer the question: What are the affordances and limitations of collaborative, classroom-based research?

\section{Research method}

This collaborative research project was situated within a designbased research framework (Plomp \& Nieveen, 2013). Designbased research involves systematic research into the design, implementation and effectiveness of interventions and innovations in complex educational contexts. The research team consisted of Julie and Yvette at the University of Melbourne and David at the University of Hong Kong, based on a research interest in the growing role of translanguaging in language education spaces, and the affordances of identity texts, as well as the translation of this work in teacher practice. As a graduate of the Master of TESOL program and a teacher in an adult TESOL education context, Hayley was particularly interested in the potential of identity texts as multimodal texts that could reflect aspects of learners' identities, as generated by learners, with colleagues Rebecca and Hon joining the project once it was established.

The project focused on the integration of four identity texts into each class curricula across the period of a ten-week term. Specifically, the texts types were 'language portraits' (Busch, 2013), 'language diaries' (de Bres \& Franziskus, 2013), 'language learning trajectory grids' (Choi \& Slaughter, 2021), and 'visual poetry' (Watson, 2015). Julie and Hayley undertook the role of 
designing the overall syllabus and had weekly discussions at the university to create lesson plans and materials for each week of the term.

The data collection process played a critical role in the research progression. Approximately 500 minutes of videorecordings across classes for all three teachers were recorded, based selectively on the days and classes where scaffolding to produce the identity texts took place. The teachers were in charge of setting up their own recordings, with Hayley collecting, labelling and uploading the recordings to a password-protected shared university drive at the end of each day. In this way, Julie was able to watch the videos in a timely manner, offering some quick suggestions through emails and sometimes through joining the teachers during lunch breaks to discuss strategies to immediately try in their classrooms. In addition, with the support of a research assistant, video-recordings related to multilingual and multimodal approaches from each teacher's classroom were identified and used in two professional development workshop days in the middle and end of the project, to help the teachers reflect on their classroom interactions. The edited videos and Hayley's role as an 'on-the-ground agent' were integral dimensions to the success of our collaboration.

Halfway through our project, the teachers were asked by their manager to give a presentation on the research as part of VicTESOL's professional learning program. For this presentation, the teachers used an action research frame to develop their ideas. Even though we had not designed our collaboration as an action research project, the agency teachers had within the project fit well with an action research lens, specifically Nunan's action research frame (1993). The process for reflecting on the action research cycle and their work on the project formed the basis of their presentations, as well as the teacher narratives presented here. The purpose of these narratives is to represent the direct voices of teachers and their experience of the project. As teachers were asked to focus on one key element of their experience, these narratives only reflect one part of their broader research experience. 


\section{Reflective Narratives: Teachers' learning journeys}

\section{Hayley's Case}

\section{The challenge}

My challenge was creating meaningful and relevant tasks that allow students to bring in their lived experiences and draw on their resources for learning. Ultimately, I wanted to find out more about my students; about their lived experiences, their linguistic resources and about what they could or couldn't do in the language classroom. This can be challenging in a foundation level class with low language and literacy learners as they struggle to express themselves in English.

What quickly emerged from being observed by Julie and from reflecting on videos of my lessons was that I was creating closed tasks that did not engage learners' knowledge, interests, and linguistic skills to help them to develop new language. The observations and videos revealed a side of my professional practice of which I was unaware: I had a deficit view of my learners that prevented me from challenging them and creating open tasks that would allow them to bring in their lived experiences and resources. Too concerned with wanting to create a harmonious environment and 'achievable' lessons, my 'deficit' perspective limited their participation. Students were passive, copying from the board and from each other as they completed simple activities that did not meaningfully relate to their lives or challenge them to develop new language.

Figure 1: Student example of body portrait, Hayley's class

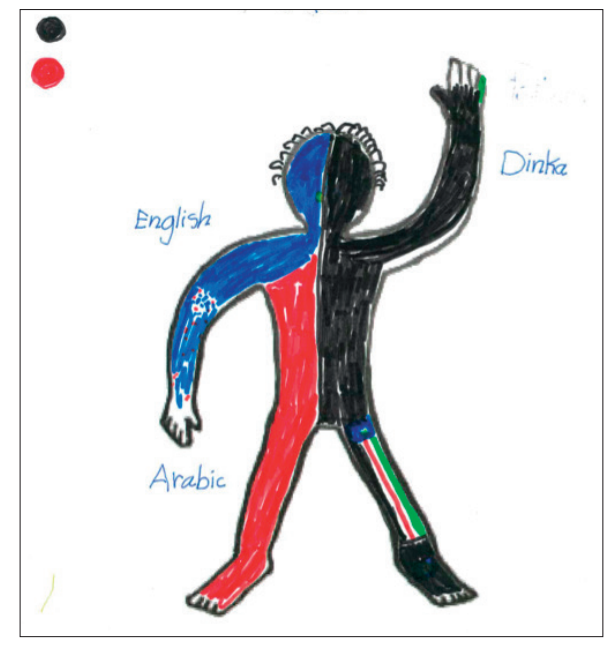




\section{The innovation}

Throughout this project I used a variety of multimodal tasks that aimed to encourage students to share their cultural and linguistic backgrounds, including language portraits (Figure 1), language diaries and language trajectory grids. As the students are in a foundational class, scaffolding and language features were significant for increasing students' understanding of what was expected of them. Prior to the students completing their own work, the teacher would teach language features and provide models as an example. Although students were often confused each time we trialled a multimodal task, new information came to the fore and I learned something new about my learners.

From the language portraits I realised the richness and complexity of languages that contribute to learners' sense of self. Although needing numerous conversations about students' languages in class, their portraits included detail of colours, cultural icons, drawings, and shading to visually represent their linguistic repertoire which included multiple languages. Each portrait was unique and offered students an alternative way of expressing the languages that they believe represent who they are. However, there were limitations and challenges related to the pedagogical approach that I took while teaching this task. Too much emphasis was placed on teaching the colours and what they symbolise, which took away the focus from students' linguistic identities. After creating their portraits, students were asked to share these with a small group of peers. This step aimed to help students realize and appreciate their own and others' linguistic identities. However, due to limitations of language, it was extremely challenging for students to articulate the choices they had made when creating their portraits and the meaning behind their visual representation. Instead, the following week the portraits were used as a prompt for writing simple sentences about their linguistic resources. My students struggle with both writing and speaking, but the portraits gave students a meaningful prompt to be able to write about themselves over a period of time. Without a prompt like this it is really hard to get students to volunteer information. Student engagement with literacy was enhanced by using the portraits as a stimulus (Figure 2). 
Figure 2: Student example of body portrait and accompanying written work, Hayley's class

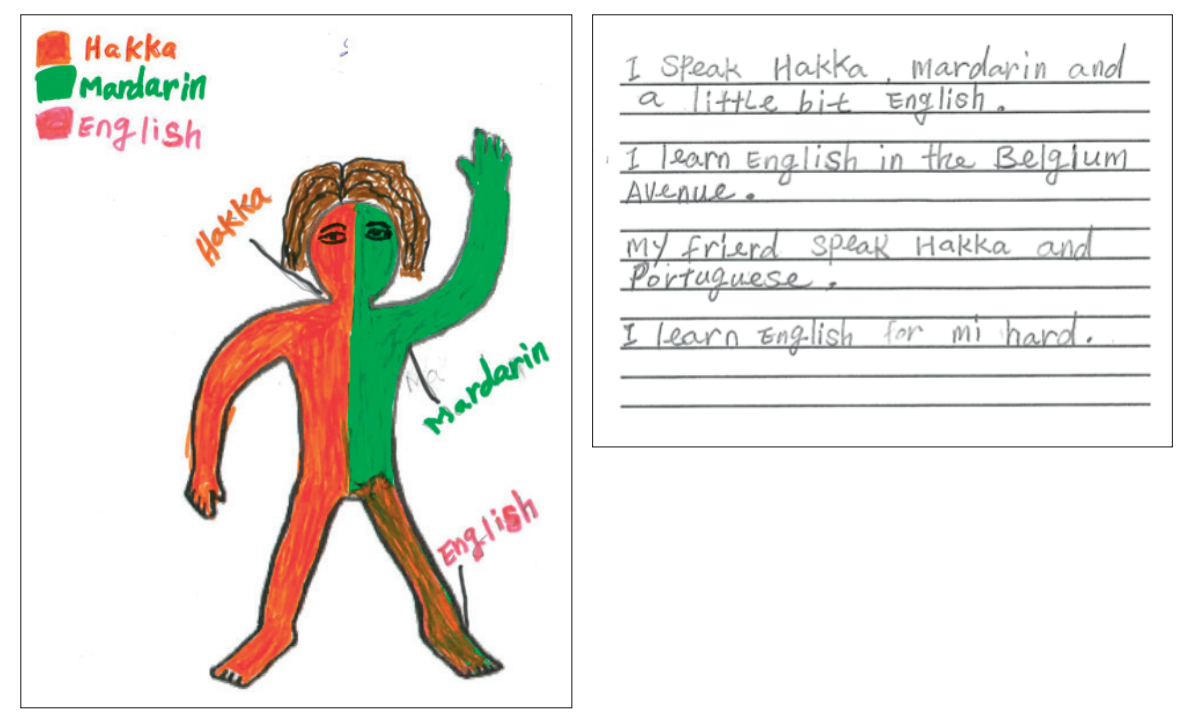

While completing learning trajectory grids, the students were given an opportunity to plot their experiences, the places they had lived and studied, along with their emotions at particular moments in time. Rich discussions relating to students' experiences represented visually on the grids emerged (Figure 3). Students openly and enthusiastically shared information about their lives. Asking questions at the time allowed stories to be shared simultaneously. Information was spontaneous, and it showed me that students want to share their stories with us.

Figure 3: Examples of learning trajectory grids, Hayley's class

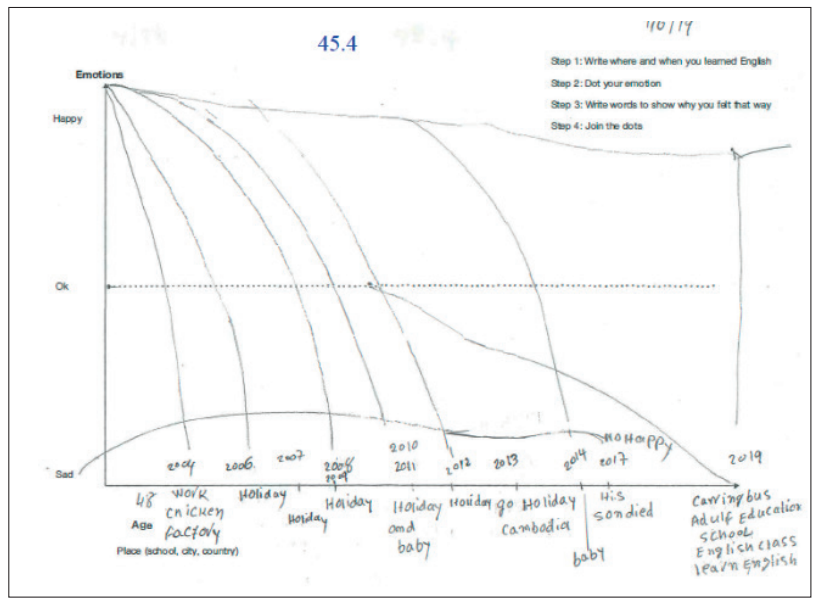


The affordances and limitations of collaborative research

45

20.3

$4 / 6 / 19$

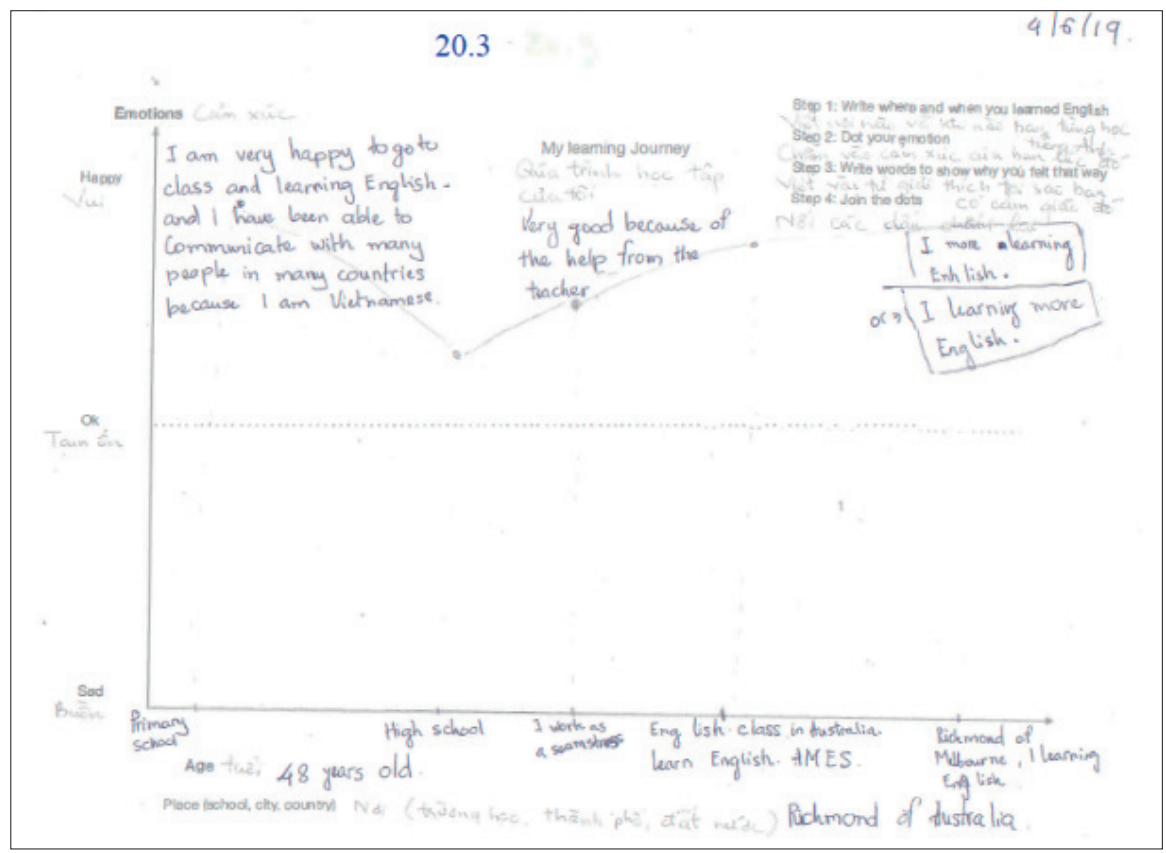

When moving into writing about the grids, students were able to independently construct sentences that were unique and personal (Figure 4).

Figure 3: An example of student written work based on learning trajectory grids, Hayley's class

I prone of my salt to lear English at my age, becomes is hard I still like come every weeks.

1 happy when my friends and my family laugh.

I happy when 1 listen funny story.

Sad moves makes me sad and Cry.

I like to travel if I can afforol.

Some time 1 got lost, where 1 am come from because I lived in many planes. When people ans me, 1 don't know how to. anwams, I have feeling my home is here 
I proud of my self to learn English at my age, because is hard I still like come every weeks.

I happy when my friends and my family laugh.

I happy when I listen funny story.

Sad moves makes me sad and cry.

I like to travel if I can afford.

Some time I got lost, where I am come from because I lived in many places. When people aus [ask] me, I don't know how to anwans [answer], I have feeling my home is here.

After class, Julie and I analysed 30 grids from two classes to identify the most prominent topics and events that students chose to include (see Figure 5). Each grid was authentic and reflected what students wanted to share. Many students had experienced the brutality of war and the challenge of leaving family and friends behind to move to another country. In the grids, students reflected on language difficulties and a lack of formal schooling. Employment and English class were generally perceived as positive.

Having had the experience of incorporating multimodal tasks into the classroom, I realise the power of student-centred, participatory tasks for low language and literacy learners. I also realised that so much can emerge when the teacher is dialogically interactive.

Figure 5: Count of themes and events from Language learning and Where I have lived trajectory grids, Hayley's class

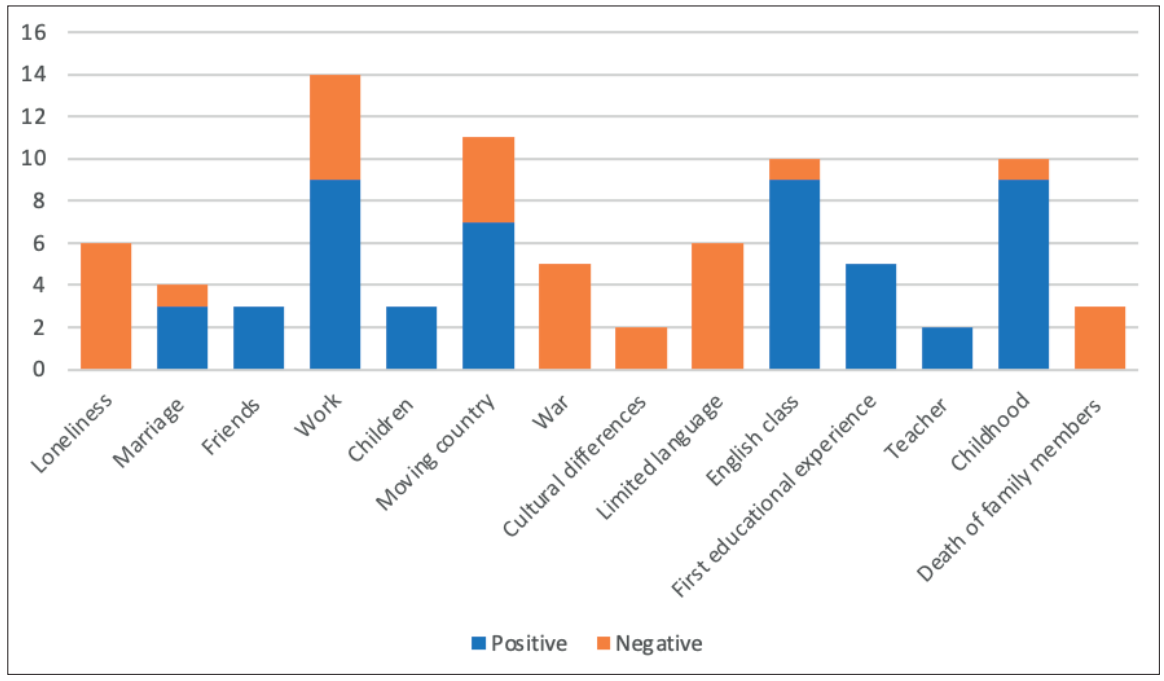




\section{Rebecca's case}

\section{Problem identification}

When Hayley asked me if I wanted to be part of a research project with Melbourne University, I had no idea what I was in for! I was happy with my teaching, at times I felt frustrated and unsure why students were passive about their learning, but students were happy and comfortable. When I asked what they wanted to learn, the answer would often be 'English'. However, I had no tools to help me improve my teaching or know how to engage students further to become active in their learning. After filming several lessons, Hayley, Han and I had a professional development day with Julie. The insight the video gave me was astounding and revealed a problem that I hadn't realized was happening. Students were unclear about what to do.

Whilst teaching I simply asked, "any questions?” to which no one replied so therefore I assumed everyone had understood and was able to continue with the task. I spent more time on the teaching point, then rushed through the instructions. Reflecting on this, I was nervous, thinking that students might be bored. One recording picked up two Chinese students debating the task in Mandarin, neither of them are very sure.

$\mathrm{W}$ : 对我们来说, 这个很抽象

[This is abstract for me.]

$\mathrm{M}$ : 我想她的意思是让我们去画, 一个开心, 一个不开心。

[I think the teacher's intention is to ask us to paint one happy and one unhappy picture.]

$\mathrm{W}$ : 但是, 就跟我们的诠释不一样的,

[But her way of understanding colours is different from our [Chinese way of] interpreting colours.]

$\mathrm{M}$ : 他叫我们要画, 什么颜色, 一个是轻松, 轻松你要什么颜色 呢? 你明白我们的意思是吗?

[She asked us to paint colours. One is about relaxing. To express relaxation, what colour represents relaxation for you? Do you understand what I mean?]

$\mathrm{W}$ : 就是不一定是对比.

[I don't think it's necessarily about comparison.]

$\mathrm{M}$ : 对比挞

[It's about comparison.] 


\section{$\mathrm{W}$ : 就是不一定是对比}

[No, not necessarily about comparison.]

As I don't speak Chinese, I was unable to understand the students' confusion. However, from the videos, it was clear that I spend too much time re-explaining instructions to students individually. So much time and energy are being spent trying to figure out instructions not only between teachers and learners but also between learners and other learners.

\section{Hypothesis}

My teaching will improve if I...

- Provide clear and simple steps that are written on the board and translated if necessary.

- Take the time to ensure every student knows the purpose and requirement of the task.

\section{Innovation}

I began writing learning objectives and success criteria in my planning and on the board. The reason to do this was to provide clarity for myself and the students. Instead of a mix of activities, the lessons became better scaffolded and each activity related back to the learning objectives. Not all students in my class can read complex sentences so I used simple language where possible, and I re-read the goal several times. We often translated key words to ensure all students had a clear understanding of the lesson to come.

Julie suggested writing a list about what to do if students needed help. At first, they were unsure what I was asking but once one student answered, the ideas flowed, and we were able to create a poster for students to refer to (Figure 6). An important change that happened here was showing students to look around the room for help. I hadn't realized that once a poster was on the wall, instead of it being an aid, it was forgotten. 
Figure 6: Asking for assistance, Rebecca's class

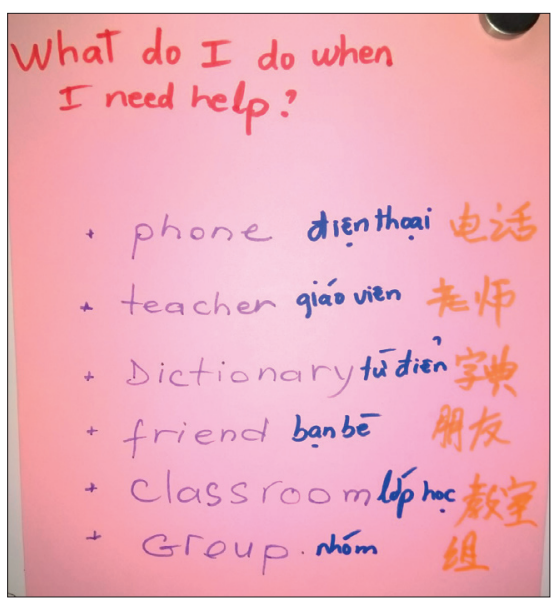

Another point Julie picked up was students didn't ask me or other students to repeat when they hadn't understood. We followed the same idea as above and created a second poster. We practiced how to say the sentences, where to put the stress and the translation (Figure 7).

Figure 7: Asking for clarification, Rebecca's class

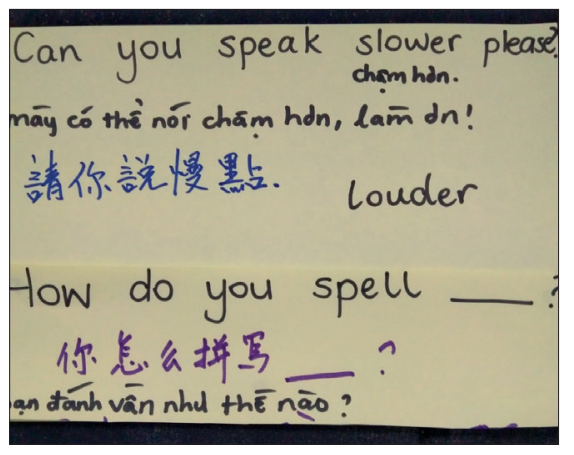

Outcome and data

Such simple changes have transformed my class into students asking each other for help, working collaboratively in different languages and asking me to "say that again". I give students more reflection time and encourage them to look back through their work. The biggest change has been using students' L1 for instructions. I feel more confident that students know what to do and the outcome from that is that students provide richer, more considered and thoughtful answers. We are also able to refer back 
to these posters constantly as a way of reinforcing the developing skills.

I have introduced a new speaking activity and as a class we created and translated a poster about the steps to complete this activity (Figure 8). In a recent lesson, the group was sitting in a circle and following some instructions, I asked students what to do - silence. I asked again - silence. I asked what is step 2 and pointed to the poster, then students were able to answer. It was really empowering for me to have resources to help students understand the task and to stop and wait until they were able to show they understood.

Figure 8: Learning circle instructions, Rebecca's class

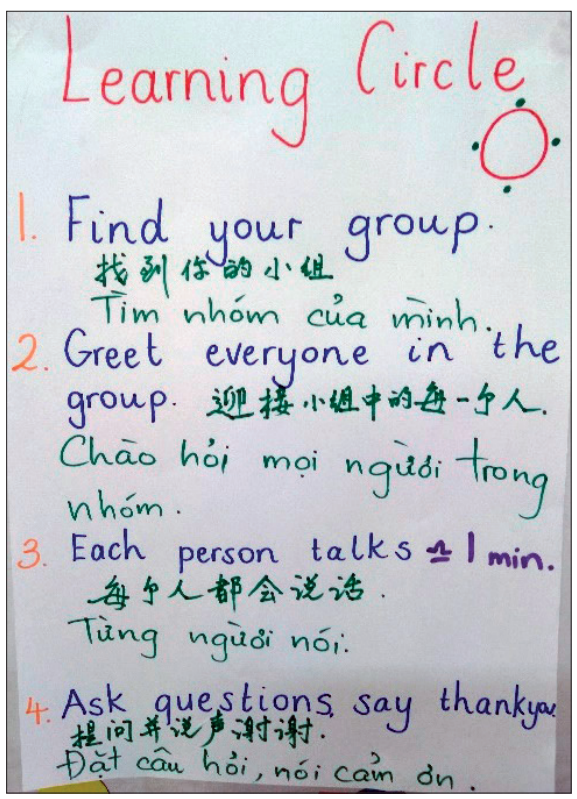

\section{Han's case}

\section{Problem identification}

My students have very diverse first languages, ranging from Vietnamese and Chinese, to Arabic, Tigrinya and so on. My first language is Vietnamese, which is also the mother tongue of more than half of my students in Richmond. However, I often feel conflicted about using Vietnamese in class. Sometimes my Vietnamese students ask me questions in Vietnamese when I know they can ask them in English. Given that I have students who speak other first languages, I was afraid of isolating them. 
I also didn't know how and when I should use L1s to help my students learn English more effectively. So, I started asking myself "How and when can I use L1s resourcefully to help student learn English?"

\section{Hypothesis}

In this project, I started with the hypothesis that "Students will engage more actively in thinking about language structures if I use their L1 in my instructions and interactions".

\section{Innovation}

One of the good things of group-teaching is it allowed me to use L1 to teach the Vietnamese group. When I did team-teaching with Hayley and Rebecca, we put students into language groups and I was responsible for the Vietnamese student group. I took this chance to interact and ask students questions in their L1, Vietnamese. For instance, instead of spelling words for students, or telling them how to say something in English, I asked my students questions to scaffold their thinking so they could come up with the answers by themselves. I also asked students questions in Vietnamese to encourage them to be more reflective about using their L1 to facilitate the acquisition of English. Given their very low English language levels, the questions would normally have been too hard or abstract to be understood in English. When I asked these questions in Vietnamese, I saw they were able to give more focused and meaningful answers in both English and Vietnamese. When writing the instructions on worksheets, or when teaching some concepts which were a little hard, I added a Vietnamese version underneath the English version (Figure 10).

Figure 8: Bilingual board work, Han's class
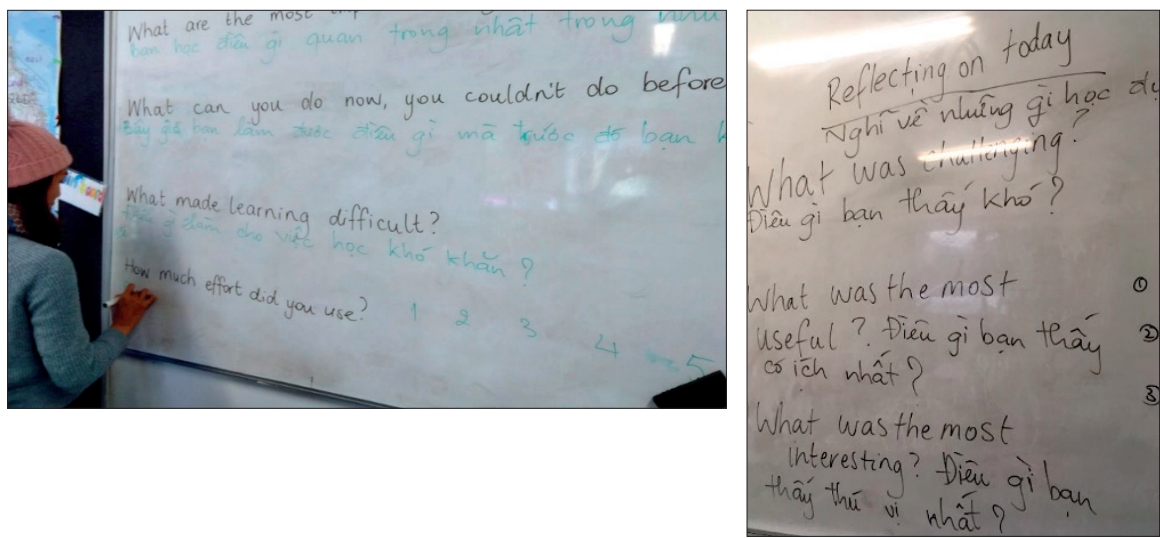
By writing Vietnamese and having students read it, I actually learned more about my students' literacy levels in Vietnamese. I discovered some had disrupted schooling and one had not been to school at all. Awareness of my students' low literacy levels in Vietnamese gave me insights into the challenges they face when learning English.

\section{Outcome and data}

While applying these changes to my instructions and interactions, I noticed and recorded that students gave deeper and more elaborate answers to the reflective questions, which I posed in both English and Vietnamese. For example, at the end of last term I asked students some reflective questions on learning like "What made learning difficult, how much effort did you use?". They gave me answers in a mix of English and Vietnamese. When they couldn't express themselves in English they switched to Vietnamese and gave some interesting answers such as "I had to use my brain to think more than before, it was harder, but I think it was good for my brain". At the end of a digital literacy afternoon session, I asked them "what was the most useful, what was the most interesting?" They said, "Studying with iPads is easier as it's very fast, but I feel like I got bored faster. While studying with the computers is very hard, once I know basic skills, I find it's more useful and more interesting". These answers help me to gain richer insights into students' needs and struggles.

In their writing, students are starting to give more genuine and focused answers in complete sentences. In Figure 11 are two writing samples from one of my students. The sample in Figure 11 (left) was produced before I introduced the reflective questioning strategy. The writing lacks depth and authenticity. It seems that she is simply going through the motions. The sample on the right in Figure 11, produced after the L1 innovation had been introduced, is longer, provides more authentic information, and reveals greater depth of thought.

Figure 11: Progression in writing pieces, Han's class

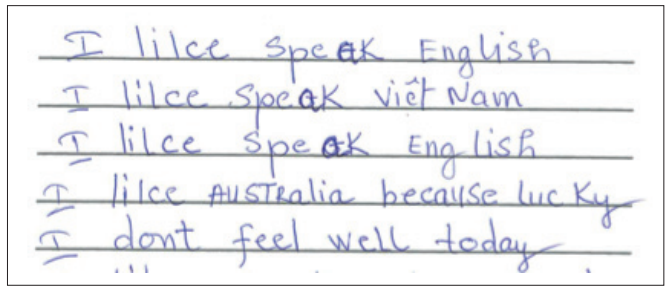




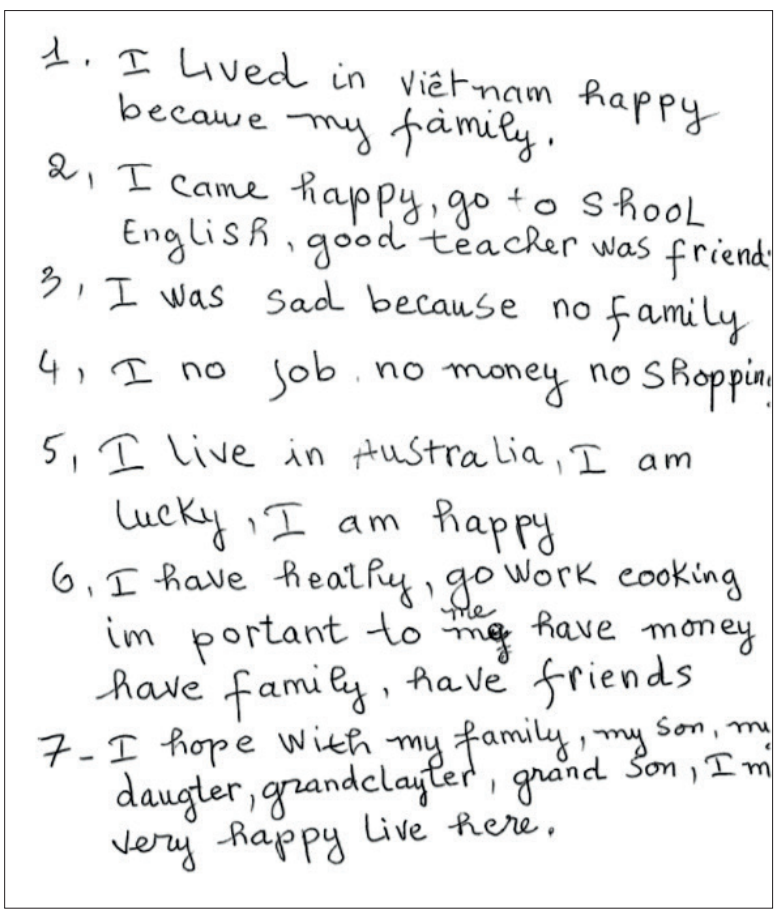

More recently I have been seeing students use Vietnamese more for purposes of learning while they are working on certain tasks. One student was discussing in Vietnamese the difference between a Vietnamese sentence structure and an English sentence structure. She was showing the other student how in English the adjective comes before a noun in a noun phrase while in Vietnamese it's the other way around. She said in Vietnamese, "In Vietnamese, we say I have a dress yellow, but in English it's I have a yellow dress, or I have a long dress, not dress long". She also tried to generalize the rule by saying, "So things and people come after colours in Vietnamese. In English it's opposite - colours go before things and people."

In another piece of video footage, I also saw two students discussing in Vietnamese how to say "I watch TV by myself". They were checking the spelling of "self" and discussing whether they should say "with myself, are myself, on myself or and myself". These students are often reluctant to write anything down until they are $100 \%$ sure but I heard one of the students say: "Just write it, if it's wrong, teacher will correct it". By drawing on students' L1 and showing students that I value their language resources, it has opened up more conversations about language between students and between students and teachers. The students now feel they can share their confusion with us. 


\section{Discussion}

In answering our research question as to the affordances and limitations of collaborative, classroom-based research, it is important to return to the key tenet that teachers' professional knowledge and practice is highly situated. This principle is indeed reflected in the differing directions that each teacher's research focused moved towards as they identified their own areas of practice to reflect on and improve, although this is also an outcome of the agentive and fluid research approach employed for this project.

Hayley's identified aim, for example, was to learn more about her students' lives and their abilities in the classroom. In introducing identity texts, and filming and reflecting on her teaching, Hayley argued that in focusing on creating a 'safe' environment for students, she could see that she was in fact positioning them as passive recipients of her highly directed teaching, and limiting her expectations of what students could achieve in the classroom. While the activities were challenging for students, Hayley began to see the opportunities they provided students with in being able to draw on all their linguistic resources; to share their stories, and to expand their writing, including the range of topics and events they shared through their work.

The language that Hayley used in her account reflects a direct line of inquiry between what she had studied in her university course, and what she sought to better understand and engage with in her teaching. The use of 'identity texts'; an understanding of 'deficit' positioning of students; the use of 'multimodal' tasks, and 'dialogic' approaches to teaching, among others, were all notions that Hayley sought to actualise - to move from her studies into her teaching practices. Indeed, her narrative finishes with a comment on a developing understanding of how to employ a more dialogic, less teacher-centred approach to her teaching.

Rebecca was motivated to join the project through Hayley's involvement. Although she stated that she was generally happy with her approach to teaching, the use of the identity texts, combined with the video-based reflection on her practice, enabled Rebecca to realise that her use of instructions could be confusing for her students. Through the development of a series of multilingual routinised phrases to assist in the understanding of classroom instructions, as well as to support students in asking for assistance, Rebecca was able to 'transform' her class into a multilingual, collaborative effort, and to continue to draw on these resources to continue to facilitate student learning. 
Through a reflection on the use of identity texts and the role of languages in classroom communication, Han was able to explore the challenge of how languages should or can be positioned in the language learning classroom. Han was able to explore her personal stance towards her own languages and teacher identity through collaborative teaching with Rebecca and Hayley. By all three teachers combining their classes for some sessions and dividing students into language groups, Han was able to work directly with a group of Vietnamese speakers, developing a deeper understanding of how to use her language skills and the students' first language to facilitate English language acquisition, including how to selectively use the written language to scaffold understanding of classroom instruction. The multilingual conversations in class provided Han with a deeper understanding of students' literacy skills and educational histories, of the aspects of learning they find engaging and challenging, and Han argues, built students confidence in the teacher and the language learning process.

As teacher-educators as well as researchers, the fluid nature of the collaboration impacted on our underlying project aims. As teacher-educators, the research project provided us with valuable insights into the critical importance of teacher agency in research collaborations, as it enabled them to effectively focus the research on pertinent areas of interest for the teachers. The invaluable role of teacher observation and reflection, particularly as guided by Julie through a frequent, iterative process over the duration of the research period, also proved critical in identifying specific teacher practices to focus on. These findings also provide us with key ideas to integrate back in to our tertiary teaching courses, both in terms of observation and reflection as a key tool in ongoing teacher development, as well as the specific practices that teachers identified and worked on throughout this research project.

As researchers, one of our initial points of interest was the affordances and limitations of identity texts with low literacy adult learners. What can students and teachers learn by using such texts? To what extent can these devices facilitate the development of language and identity? What can this tell us about the positioning of linguistic and cultural resources in the classroom? While there are some findings we can report on in relation to this, the research focus really shifted quite early on in the project to the use of identity texts as a tool to mediate professional learning, rather than as an object of study in and of themselves. From there, it shifted again, focusing on individual pedagogical concerns and 
challenges as identified through the collaborative reflections. These shifts were directly influenced by the 'messy' and 'fluid' nature (Burns \& Edwards, 2014, p. 67) of the research project and the ongoing collaborative consultations and professional learning sessions led by Julie. While the findings from this project are rich and informative, a more prolonged, multi-stage research process was needed to investigate the affordances of the identity texts, including the student and teacher experience.

Without doubt the collaborative nature of the project was incredibly beneficial for all parties. A more challenging aspect was the writing up and reporting of the research, which we also tried to make as collaborative as feasible. While teacher voice is directly reported in this article, and all teachers had the opportunity to read and comment on the draft paper, the end of funding; the timelines of research writing; the article submission and review process, and the interjections of unexpected events such as COVID-19, have all created a longer and thinner line of collaboration across the writing stage. With the best of intentions, the article includes the voice of all research parties, as recognised in the authorship of the article.

\section{Concluding remarks}

Collaborative research is messy; necessarily so if we are to effectively interrogate the nexus of SLA research and teaching pedagogy. Within the complex and competing aims of funding and research mechanisms, and those of research participants, explicitly identifying and reflecting on the motivations and aims of all research participants allows for realistic and effective research work. Such work involves being agile and responsive to directions of inquiry as they unfold, and less bound by the limiting timeframes and research focus often dictated by funding mechanisms and academic conventions. Research projects focused on iterative cycles of reflection and implementation are arguably more likely to attend to a range of research aims and to better facilitate reciprocal knowledge development and transfer across the research and practice spaces.

\section{Statement on compliance with ethical standards}

This research project was supported by a grant from the VicTESOL association, as well as an internal grant from the Melbourne Graduate School of Education. Ethics approval was secured from the University of Melbourne and informed consent was obtained from all research participants. 


\section{References}

Abur, W., \& Spaaij, R. (2016). Settlement and employment experiences of South Sudanese people from refugee backgrounds in Melbourne, Australia. Australasian Review of African Studies, 37(2), 107-128. https://doi.org/10.22160/ 22035184/ARAS-2016-37-2/107-128

Barnard, R., \& Burns, A. (2012). Introduction. In R. Barnard \& A. Burns (Eds.), Researching language teacher cognition and practice: International case studies (pp. 1-10). Bristol; Buffalo: Multilingual Matters.

Bigelow, M., \& Lovrien Schwarz, R. (2010). Adult English language learners with limited literacy. Retrieved from https://lincs. ed.gov/publications/pdf/ELLpaper2010.pdf

Blackmer, R., \& Hayes-Harb, R. (2016). Identifying effective methods of instruction for adult emergent readers through community-based research. Journal of Research and Practice for Adult Literacy, Secondary, and Basic Education, 5(2), 35-49.

Burns, A. (2019, April). What can teacher-researchers learn from academic research? IATEFL Liverpool Conference. Liverpool, UK.

Burns, A., \& Edwards, E. (2014). Introducing innovation through action research in an Australian national programme: Experiences and insights. In D. Hayes (Ed.), Innovations in the continuing professional development of English language teachers (pp. 65-88). London: British Council. Retrieved from https://www.teachingenglish.org.uk/sites/teacheng/files/ pub_E168\%20Innovations\%20in\%20CPD_FINAL $\% 20$ V2\%20web.pdf

Burt, M., Peyton, J. K., \& Adams, R. (2003). Reading and adult English language learners: A review of the research. Washington, DC: Center for Applied Linguistics. Retrieved from https:/ / files.eric.ed.gov/fulltext/ED505537.pdf

Busch, B. (2013). The linguistic repertoire revisited. Applied Linguistics, 33(5), 503-523. https://doi.org/10.1093/applin/ ams056

Choi, J., \& Slaughter, Y. (2021). Challenging discourses of deficit: Understanding the vibrancy and complexity of multilingualism through language trajectory grids. Language Teaching Research. Advanced online publication https://doi. org $/ 10.1177 / 1362168820938825$ 
Cross, R. (2010). Language teaching as sociocultural activity: Rethinking language teacher practice. The Modern Language Journal, 94(3), 434-452.

Cummins, J. (2007). Rethinking monolingual instructional strategies in multilingual classrooms. Canadian Journal of Applied Linguistics, 10(2), 221-240.

Cummins, J. (2009). Transformative multiliteracies pedagogy: school-based strategies for closing the achievement gap. Multiple Voices for Ethnically Diverse Exceptional Learners, 11, 38-56.

Cummins, J., \& Early, M. (Eds.).(2011). Identity texts: The collaborative creation of power in multilingual schools. Stoke-on-Trent, UK: Trentham Books.

Cummins, J., Hu, S., Markus, P., \& Montero, M.K. (2015). Identity Texts and Academic Achievement: Connecting the Dots in Multilingual School Contexts. TESOL Quarterly, 49(3), 555581.

de Bres, J., \& Franziskus, A. (2013). Multilingual practices of university students and changing forms of multilingualism in Luxembourg. International Journal of Multilingualism. 11(1), 62-75. doi:10.1080/14790718.2013.831098.

DeCapua, A., \& Marshall, H. W. (2011). Breaking new ground: Teaching students with limited or interrupted formal education. Ann Arbor: University of Michigan Press.

DeCapua, A., Marhsall, H. W., \& Fryland, N. (2018). The transformational learning journey of a novice ESL teacher of low-literate adults. Journal of Transformative Education, 16(1), 17-38. https://doi.org/10.1177/1541344617704645

Ellis, E. M. (2016). "I May Be a Native Speaker but I'm Not Monolingual": Reimagining All Teachers' Linguistic Identities in TESOL. TESOL Quarterly, 50(3), 597-630. https://doi.org/10.1002/tesq.314

Ellis, R. (1997). SLA and language pedagogy: An educational perspective. Studies in Second Language Acquisition, 19, 69-92. https://doi.org/10.1017/S0272263197001058

Freeman, D., \& Richards, J. C. (2002). Prologue: A look at uncritical stories. In D. Freeman \& J. C. Richards (Eds.), Teacher learning in language teaching (pp. 1-6). New York: Cambridge University Press. 
Grierson, A. (2010). Changing conceptions of effective teacher education: The journey of a novice teacher educator. Studying Teacher Education, 6, 3-5. https://doi.org/10.1080/ 17425961003668898

Johnson, K. E. (2009). Second language teacher education: A sociocultural perspective. New York: Routledge.

MacPhail, A., Ulvik, M., Guberman, A., Czerniawski, G., Oolbekkink-Marchand, H., \& Bain, Y. (2019). The professional development of higher education-based teacher educators: Needs and realities. Professional Development in Education, 45(5), 848-861. https://doi.org/10.1080/194152 57.2018 .1529610

Moosa, I. A. (2018). Publish or perish: Perceived benefits vs unintended consequences. Cheltenham, UK: Edward Elgar Publishing.

Nassaji, H. (2012). The relationship between SLA research and language pedagogy: Teachers' perspectives. Language Teaching Research, 16(3), 337-365. https://doi. org/10.1177/1362168812436903

Nunan, D. (1993). Action research in language education. In J. Edge \& K. Richards (Eds.), Teachers develop teachers research: Papers on classroom research and teacher development (pp. 39-50). Oxford: Heinemann.

Plomp, T., \& Nieveen, N. (2013). Educational Design Research. Enschede, the Netherlands: Netherlands Institute for Curriculum Development (SLO). Retrieved from http:// downloads.slo.nl/Documenten/educational-designresearch-part-a.pdf

Scanlon Institute. (June 2019). Australia's English Problem: How to renew our once celebrated Adult Migrant English Program. Retrieved from http://scanloninstitute.org.au/static/ narrative_booklet_3.025d4a21.pdf

Shulman, L. S. (2007). Practical wisdom in the service of professional practice. Educational Researcher, 36(9), 560-63. https://doi.org/10.3102/0013189X07313150

Slaughter, Y., \& Cross, R. (2020). Challenging the monolingual mindset - understanding plurilingual pedagogies in English as an Additional Language (EAL) classrooms. Language Teaching Research. [Online First] https://doi. org/10.1177/1362168820938819. 
Smith, K. (2017). Learning from the past to shape the future. European Journal of Teacher Education, 40(5), 630-46. https:/ / doi.org/10.1080/02619768.2017.1385058

Spada, N. (2013). SLA research and L2 pedagogy: Misapplications and questions of relevance. Language Teaching, 48(1), 69-81. https://doi.org/10.1017/S026144481200050X

VanPatten, B., \& Williams, J. (2015). Introduction: The nature of theories. In B. VanPatten, \& J. Williams. (Eds.), Theories in second language acquisition: An introduction (pp. 1-16). New York: Routledge.

Watson, R. (2015). Talking back to the world: Turning poetic lines into visual poetry. In L. Christensen \& D. Watson (Eds.), Rhythm and resistance: Teaching poetry for social justice (pp. 47-50). Milwaukee: Rethinking Schools.

Dr Yvette Slaughter, The University of Melbourne

Dr Yvette Slaughter is Senior lecturer in Language and Literacy Education within the Melbourne Graduate School of Education. Her research interests focus on plurilingual pedagogies, multilingualism in education, language policy and planning, and language program implementation. Yvette is currently working on research focusing on the use of plurilingual pedagogies and engagement with linguistic repertoires in early childhood, primary/secondary and adult educational contexts.

ymslau@unimelb.edu.au

Dr Julie Choi, The University of Melbourne

Dr Julie Choi is Senior Lecturer in Education (Additional Languages) at the Melbourne Graduate School of Education. She is co-author of Language and Culture: Reflective Narratives and the Emergence of Identity (2010) and Plurilingualism in Teaching and Learning: Complexities across Contexts (2018), and sole author of Creating a Multivocal Self: Autoethnography as Method (2017).

julie.choi@unimelb.edu.au

Professor Emeritus David Nunan, The University of Hong Kong

David Nunan is Professor Emeritus of Applied Linguistics at the 
University of Hong Kong and Distinguished Research Professor at Anaheim University. $\mathrm{He}$ is former President of TESOL International and is currently a Trustee and Executive Committee member of The International Research Foundation for English Language Education (TIRF). He has published over 30 books on curriculum development, language teaching methodology, research methods, and teacher education. He has published fifteen EFL textbook series. Go For It is the largest selling series in the world with global sales of over four billion copies.

Ms Hayley Black, Carringbush Adult Education

Hayley Black is an English as an Additional Language (EAL) teacher with a secondary school media and EAL teaching background and a Masters in TESOL. She currently teaches EAL and digital literacy to adults from migrant and refugee backgrounds in a community setting, at Carringbush Adult Education.

\section{Ms Rebecca Grimaud, Carringbush Adult Education}

Rebecca Grimaud has been a teacher in a variety of settings in England, France and Australia for over ten years. She joined Carringbush as a literacy volunteer in 2017 and now teaches low level literacy learners. Rebecca also teaches French at a local Primary school. She is interested in the use of gestures and explicit pronunciation to help learners increase their confidence in speaking.

Ms Hân Trinh, Carringbush Adult Education

Hân Trinh has worked as an ESL teacher in Vietnam and Australia for more than 5 years. She studied her Masters of TESOL in Melbourne and joined Carringbush teaching team in 2018. Hân has mainly worked with low level literacy learner groups at Carringbush and is interested in teaching explicit pronunciation and incorporating multilingual teaching approaches into her practice. 